\title{
A means-end analysis of Special Olympics volunteers
}

\author{
Breanne Long and Marni Goldenberg* \\ Recreation, Parks and Tourism Administration Department, California Polytechnic State \\ University, San Luis Obispo, CA 93407, USA
}

\begin{abstract}
Many non-profit recreation, parks and tourism organizations utilize volunteers. To attract and retain volunteers, these organizations must discover why volunteers donate time. This study used means-end theory to examine the attributes, consequences and values associated with volunteering for the San Luis Obispo (SLO) County Special Olympics as well as the volunteer demographics. Study participants included 55 volunteers who were asked demographic and open-ended questions during interviews at sporting and training events. Results showed most volunteers were parents of an athlete in the program and either had been involved in the program for less than a year and donated less than 60 hours per year, or had been involved for more than 5 years and donated hundreds of hours per year. Many individuals volunteer so their child athlete will receive the benefits of sport, including increased social contact for their child, which leads them to believe their child will have warm relations with others and have a sense of belonging which leads to having increased self-confidence, leading to the athlete enjoying their life more. Parents perceive that their child athlete receives these benefits of sport and this perception in turn generates a positive effect on the parent.
\end{abstract}

Beaucoup d'organismes de loisirs à but non lucratif font appel à des bénévoles. Pour attirer et conserver ces bénévoles, ces organisations doivent déduire pourquoi les bénévoles consacrent du temps a ces activités. Cette étude de la théorie des moyens utilisés pour fin à examiner les attributs, les conséquences, les valeurs associés au bénévolat, ainsi que les caractéristiques démographiques des bénévoles associés aux Jeux olympiques spéciaux dans le comté de San Luis Obispo (SLO). 55 bénévoles participants à l'étude ont été posés des questions démographiques et des questions ouvertes reliées à des événements sportifs. Les résultats démontrent que la plupart des bénévoles sont des parents d'athlète impliqué dans les programmes, que ces bénévoles sont impliqués dans le programme depuis moins d'un an et contribue moins de 60 heures par an. D'autres bénévoles par contre, furent impliqués pendant plus de cinq ans et contribue des centaines d'heures annuellement. Les avantages du bénévolat selon ces individus sont les bienfaits du sport, notamment le contact social accru pour leurs enfants, le sens d'appartenance, et la confiance en soi. Les parents perçoivent que leurs enfants athlète reçoivent ces bienfaits du sport et cette perception à son tour, génère un effet positif sur les parents. 


\section{Introduction}

Not-for-profit organizations provide important programs to the public. Not-for-profits often resume responsibility for programs that have been discontinued because of lack of funding or other factors, thereby enabling the programs and services to continue to operate. Many recreation, parks and tourism programs are run by not-for-profit organizations, such as Special Olympics.

The most important asset of not-for-profits is volunteers, and as more and more notfor-profits are forming, volunteers have more options (Penner, 2004). Today's volunteers are not as loyal as the volunteers of the past (Ellis, 2005; Hustinx \& Lammertyn, 2004; Rehberg, 2005; Winter, 1998). "New age" volunteers want to work on short-term projects and volunteer at times that are convenient for them. Accordingly, not-for-profit organizations must be competitive to succeed in recruiting volunteers. If not-for-profits can create successful volunteer programs, they can capture new volunteers and retain current ones. By retaining current volunteers, organizations incur fewer costs and can more effectively direct financial resources toward the organization's mission.

The San Luis Obispo (SLO) County Special Olympics in California is a not-for-profit organization that provides sports and other recreational activities free of cost to individuals with intellectual disabilities. It operates with only two full-time paid staff and one parttime paid staff. Two hundred volunteers help facilitate the program. Volunteers contributed 18,500 volunteer hours in 2004 according to the SLO County Special Olympics staff. "Special Olympics Southern California would not exist today without the time, energy, commitment and enthusiasm of its volunteers" (Special Olympics, n.d.).

The purpose of this study was to determine the attributes, consequences and values individuals associate with volunteering for the Special Olympics. An understanding of volunteers' values and reasons for volunteering with the Special Olympics will enable program coordinators to tailor volunteer programs to better suit the values of volunteers. This research addressed the following questions:

(1) What are the attributes that individuals associate with volunteering for the SLO County Special Olympics?

(2) Do attributes, consequences and values differ according to gender and length or degree of involvement?

(3) What are the demographics of volunteers for the SLO County Special Olympics?

(4) What are the specific values associated with volunteering?

\section{Literature review}

\section{Volunteering}

There have been numerous studies on volunteers and their reasons for volunteering (Allison, Okun, \& Dutridge, 2002; Clary et al., 1998; Finkelstein \& Penner, 2004; Fletcher \& Major, 2004; Greenslade \& White, 2005; Houle, 2001). The most pervasive approach to studying volunteer motivation is the functional approach (Allison et al., 2002; Clary et al., 1998; Finkelstein \& Penner, 2004; Fletcher \& Major, 2004; Greenslade \& White, 2005; Houle, 2001). The functional approach to motivation follows the idea that motives represent the functions served by the action, and one action can serve many different functions. The functional approach uses the following motives to understand volunteering behaviour: career, esteem, protective, social, understanding, value enjoyment, religiosity and team building (Allison et al., 2002). An assumption of those using the functional approach is that 
the decision to volunteer is a rational process. Volunteering behaviour is preceded by a cognitive evaluation of benefits derived from volunteering (Greenslade \& White, 2005).

Numerous volunteer studies based on the functional approach use the volunteer functions inventory created by Clary, Snyder, and Ridge (1992) when looking at volunteer motives (Clary et al., 1998; Clary, Snyder, \& Stukas, 1996; Fletcher \& Major, 2004; Greenslade \& White, 2005). The instrument based on this inventory has questions addressing six different functions of volunteering. The values function involves altruistic and humanitarian concern for others. For example, an individual would volunteer to help others. The understanding function deals with individuals taking advantage of an opportunity to use skills that would go unused otherwise. An example of the understanding function is someone who volunteers to use a skill such as another language that they otherwise would not have the opportunity to use. Enhancement function is the positive effect of growing psychologically. An individual who volunteers to personally grow is an example of the enhancement function. Career function builds an individual's resume. Someone who volunteers so that they can put the experience on their resume illustrates the career function of volunteering. Social function involves individuals' motives to be with friends, peers or to do something that will be viewed favourably by others. Protective function occurs when volunteers feel guilty because of their fortune.

A study by Houle (2001) also used the functional approach to evaluate volunteer motivation to determine if specific types of volunteering roles satisfy certain motives, and if volunteers prefer tasks consistent with their motives. Houle found that volunteer roles did in fact satisfy volunteer motives and individuals preferred tasks that best satisfied these personal motives.

The functional approach to understanding volunteer motives examines the functions and activities associated with motivations for volunteering. This approach does not help identify why individuals choose to volunteer for a specific organization. To do this one must identify specific characteristics of the volunteer opportunity that volunteers use to differentiate volunteer experiences.

Recently, Rehberg (2005) looked at the motivations for international volunteering in young adults in Switzerland. Rehberg examined 12 different motives that were classified into three groups: "quest for one's self," "quest for the new" and "achieve something positive for others." This study used semi-structured interviews with open-ended questions about motivation on 118 individuals. It was found that all three motives occurred frequently: $77 \%$ were motivated by achieving something positive for others, $75 \%$ were motivated by the quest of something new and $67 \%$ were motivated by the quest for one's self. Most often the motives did not occur alone (Rehberg, 2005). These three motives were also identified in this study and were obtained through a similar semi-structured interview process.

Many authors (Ellis, 2005; Hustinx \& Lammertyn, 2004; Rehberg, 2005; Winter, 1998 ) believe that there is a new type of volunteer. The new type of volunteer is projectoriented, has higher expectations for time and content of volunteer jobs and is motivated by his/her stage in life and personal goal setting. In the past, volunteers would contribute for long periods of time where participation was based on commitment and altruistic motives. Volunteering would frequently occur in groups. These volunteers were also very attached to their organization's values and goals (Ellis, 2005; Hustinx \& Lammertyn, 2004; Rehberg, 2005; Winter, 1998).

There are many changes occurring in the volunteer sector as volunteers have new expectations and as many new volunteer organizations are developed (Ellis, 2005; Hustinx \& Lammertyn, 2004; Rehberg, 2005; Winter, 1998). As competition for volunteers increases, there has become an intertwining of the private, public and community sectors 
that has given rise to a new managerial outlook for non-profits (Hoye, 2004; Jimenez \& Fuertes, 2005).

\section{Means-end theory}

Means-end theory was developed by Gutman (1982) to explain consumer behaviour. In addition to understanding consumer behaviour, means-end theory has been used in leisure research. This technique was used by leisure researchers to understand ski destinations (Klenosky, Gengler, \& Mulvey, 1993), factors that influence greenway use (Frauman \& Cunningham, 2001) and behaviour patterns of museum visitors (Jansen-Verbeke \& van Rekom, 1996). Even more recently, leisure researchers have applied means-end theory in an adventure recreation setting to understand the outcomes of this type of recreation participation (Goldenberg, Klenosky, O’Leary, \& Templin, 2000; Goldenberg, McAvoy, \& Klenosky, 2005; McAvoy, Holman, Goldenberg, \& Klenosky, 2006).

This more recent type of application in recreation is different from previous leisure research in which the previous research focused on the consumer and marketing aspect (Klenosky et al., 1993) instead of focusing on understanding the outcomes and personal values of recreation (Goldenberg et al., 2000, 2005; McAvoy et al., 2006). This more recent style of applying means-end theory to recreation is very pertinent to volunteer motivation research and will help to provide more insight than traditional use of the theory.

Through means-end theory, Gutman (1984) suggested a linkage between product attributes, consequences of consumption and personal values. By linking these categories, means-end chains (MECs) are produced. The means are equivalent to services or products and the ends are the values that are important to the consumers. There are two main assumptions of the theory: (1) all consumer actions have consequences and (2) consumers learn to associate specific consequences with certain actions that they take. The guiding point of this model is that consumers select actions that lead to desired consequences and decrease unwanted consequences (Gutman, 1984).

Attributes are apparent physical or psychological identities of products that consumers use to distinguish between them (Gutman, 1982). These attributes are not what consumers value about the product but rather their ability to help the consumer achieve a desired outcome or consequence. Consequences are defined as physiological or psychological outcomes that consumers expect to accrue from their consumption of products in certain situations (Gutman, 1982). Manyiwa and Crawford (2002) stated that values are the guiding force of individuals' desired outcomes. Values are a consumer's preferred end state, for example, security or pleasure (Gutman, 1982). An example of the responses from a means-end interview about ropes courses includes the attribute "requires help from others" which then leads to the benefit "encourages us to work as a team" which then leads to a higher benefit of "gets the task done" which finally links to the value of "we accomplish something" (Goldenberg et al., 2000).

Nine core values have been identified in means-end research including a sense of belonging, excitement, warm relationships with others, self-fulfilment, being well respected, fun and enjoyment of life, security, self-respect and a sense of accomplishment (Kahle, 1983; Veroff, Douvan, \& Kulka, 1981). This List of Values was created from the values proposed by many different authors including Feather (1975), Maslow (1954) and Rokeach (1973). Researches look for these values in the interview responses but are open to identifying new values, should the responses warrant a new value category.

Maslow (1954) created the hierarchy of values whereas Rokeach examined 18 terminal values and other aspects of values research (Bearden, Netemeyer, \& Mobley, 1993). The 
List of Values was tested by Kahle (1983) through a study of 2264 Americans. Kahle (1983) found that the List of Values significantly correlated with multiple measures of mental health and well-being as well as societal adaptation and self. Research using the means-end approach has revealed similar lists of values (Goldenberg, 2002; Goldenberg, Pronsolino, \& Klenosky, 2006). Participants in this study also identified some of the same values when describing the reasons why they volunteer for the SLO County Special Olympics.

Once attributes, consequences, values and their links are identified during the interview process, each individual response is combined to create a Hierarchical Value Map (HVM). HVMs illustrate grouped survey responses and the links between them. HVMs are examined to determine overriding themes in the data and help to show links between attributes, consequences and values. An interview participant may provide the following response when asked why they drink coffee, which would in turn be illustrated as a path in an HVM: thirst quenching leads to better concentration, which leads to retaining more, which leads to better grades, which leads to higher GPA (Grade Point Average), which in turn leads to a better job and finally leads to success, as illustrated in Gutman (1997). These types of ladders and HVMs are also useful in thinking about coffee in a different way and creating marketing and advertising strategies (Gutman, 1984).

Means-end theory uses questionnaires and interviews to understand the attributes of, consequences from and values that people assign to different products or services. The interviewing technique is believed to be more comprehensive because the interviewer can make sure all questions are answered and continue to probe the participant to get ladders (Baker, Thompson, \& Engelken, 2004; Gengler, Mulvey, \& Oglethorpe, 1999; Gutman \& Miaoulis, 2003).

Means-end theory has been applied to various disciplines. Historically, it has been used to examine consumer behaviour in beverage use (Gutman, 1984), recycling behaviour (Bagozzi \& Dabholkar, 1994), weight loss (Pieters, Baumgartner, \& Allen, 1995), higher education (Gutman \& Miaoulis, 2003) and to understanding the importance of product attributes and consequences using cameras (Graeff, 1997).

Means-end theory has been applied to various types of leisure but has not been applied to volunteerism which is also considered a form of leisure as it provides opportunities to people to engage in recreation, self-determination, personal development and service to others (Twynam, Farrell, \& Johnston, 2002/2003). Leisure is also defined as a psychophysiological experience which in itself is self-rewarding, occurs during free time and carries a sense of autonomy (Iso-Ahola, 1999; Manfredo, Driver, \& Tarrant, 1996). Volunteerism also corresponds with this definition of leisure in that it is rewarding, occurs during free time and that most individuals are not required to participate. Using means-end allows researchers to use previously identified values and functions that volunteering serves but also allows the researchers to identify any new values associated with volunteering for this specific organization.

\section{Methods}

\section{Setting and participants}

All volunteers (including head coaches, assistant coaches, drivers/chaperones and helpers at winter sports trainings) were asked to participate in the study. Participants were a convenience sample of 200 SLO County Special Olympics volunteers and were interviewed in person at eight different locations where SLO County Special Olympics winter sports took place. No volunteers were purposefully excluded. Subjects were interviewed at in-season 
sports practices including floor hockey, swimming and basketball practices as these were the only sports occurring during the time data was collected. During this period, one floor hockey tournament also took place where volunteers were invited to participate.

\section{Instrument design}

The interview questions were patterned after other means-end studies (Goldenberg, 1997; Goldenberg et al., 2000; Walker, 1988). Interview questions can be asked through hard or soft laddering (Costa, Dekker, \& Jongen, 2004). During hard laddering, the participant is encouraged to produce associations between elements in ladders that are increasingly abstract. Soft laddering is the natural unobstructed flow of speech from the participant during the interview. After the interview, the researcher identifies the attributes, consequences and values provided by the interviewee during the conversation. The research then constructs associations between attributes, consequences and values based on the interviewee's responses.

This study used hard laddering technique rather than soft laddering technique as is common in studies involving more than 50 subjects (Costa et al., 2004). During hard laddering, the participant was asked to produce associations between elements in ladders that were increasingly abstract. Once the instrument was designed, two means-end experts from California Polytechnic State University reviewed the interview questions and a pilot study was conducted.

Ten volunteers, similar to the volunteers for the actual study, were interviewed during December 2005 to pilot test the interview questions. These ten volunteers were interviewed at the floor hockey training and at a winter social. The responses to the interview were examined to see if any changes were needed. The following changes were made.

The answers for the question regarding length of time volunteered for the SLO County Special Olympics were increased. Originally, the highest answer was 5 or more years. After the first 10 interviews, data showed many individuals had volunteered for 10 or more years. Therefore, the increment that the answers increased was changed as was the maximum number of years. One additional change was made in the script wording for question 7. It was determined that the interest was not in the outcomes of volunteering but the actual reason for volunteering.

The interview was broken up into two sections. The first section asked demographic questions including sex, age and education level. The participants were also asked their volunteer position at the Special Olympics, how many years they had been volunteering and how many hours a year they volunteered. In the interview, individuals had different choice brackets on the number of hours volunteered per year.

In the second section, subjects were asked to provide their own reasons for volunteering and then rate their reasons for volunteering in order of importance. They were then asked why the reasons were important until ladders were created and they could no longer answer.

\section{Data analysis}

The first step of data analysis was to code the ladders into attributes, consequences and values. Each reason that the subject provides for volunteering and the corresponding answers of why that specific reason they provided is important is considered a ladder. Each time the researcher asks a subject why a specific answer is important that new answer is linked to the original reason for volunteering. These links between why an individual volunteers for the Special Olympics form ladders. 
The researcher examined each subject's responses, categorized the responses into general themes and then assigned specific names to the themes. For example, if a subject stated that they volunteered because they had an athlete in the program that response would be categorized as "athlete." Once all of the responses were names they were assigned as an attribute, consequence or values based on their meaning. In continuing the example from above, the response categorized as "athlete" would be classified as an attribute because it relates to a physical identity regarding the Special Olympics.

These ladders were entered into a software program used to organize means-end data, LadderMap (Gengler \& Reynolds, 1995). As the ladders were entered, content codes were assigned. Content codes are synonyms assigned and designated by the researcher, to best classify participants' responses.

Multiple phases were used to ensure that the content codes were reliable and valid, following a process used in prior research (Goldenberg, 2002; Goldenberg et al., 2000). The researcher was the first to code the data. An independent coder thereafter independently coded 274 ladders out of a total of 484 ladders, $56.6 \%$ of the data. The researcher supplied the independent coder with content codes and their definitions and provided clarification as necessary.

The independent coder assigned the content codes the researcher established to each attribute, consequence and value. Once he assigned content codes to $56 \%$ of the data, these assignments were compared to those made by the principal researcher.

There was $76.6 \%$ agreement between the independent coder and the researcher. This level of intercoder agreement was similar to the prior means-end research (Goldenberg, 2002; Goldenberg et al., 2000; Klenosky et al., 1993). All disagreements were examined and resolved by another independent researcher and the original researcher. Another independent experienced means-end theory researcher performed final check of the codes to ensure the content codes fairly represented the participants' interview responses.

After this process, the program creates an implication matrix to analyze the data (see Table 1). The implication matrix summarizes the number of times codes were associated in all of the ladders. This matrix illustrates the sum of the direct and indirect links corresponding to an overall research question (Goldenberg, 2002). From the implication matrix, HVMs were created by the researcher using LadderMap Software.

HVMs show the links between attributes, consequences and values, derived from the interview participants' responses, by connecting circles with lines, creating ladders moving from concrete ideas to increasingly abstract ideas. In Figure 1, a ladder starts with the attribute at the bottom of the page, "volunteering" which is connected via line to the consequence located in the middle of the page, "relieve stress" which in turn is connected at the top of the page to the value "self-improvement/self-esteem/self-fulfilment." The thickness of the line illustrates the number of times the link occurred, the thicker the line the more occurrences. In Figure 3, there is a very strong connection between the attribute "social contact/acceptance" and the consequence "learning from interactions with others." A less common link, and thinner line, is represented in the link between the attribute "athlete" and the attribute "new experiences." The size of the circle showed the number of times the synonym was mentioned. In Figure 2, the largest circle represents the consequence "learning from interactions with others" illustrated that it was mentioned more frequently. The LadderMap program determined the size of the synonym circles and line thickness between circles based on the number of times it was mentioned by participants in the study.

Cut-off points, provided by the LadderMap software, were instituted by the researcher, so that rarely mentioned ladders were not illustrated, allowing the major themes to be easily identified. The lowest data cut-off point (highest percentage of data shown) was chosen 


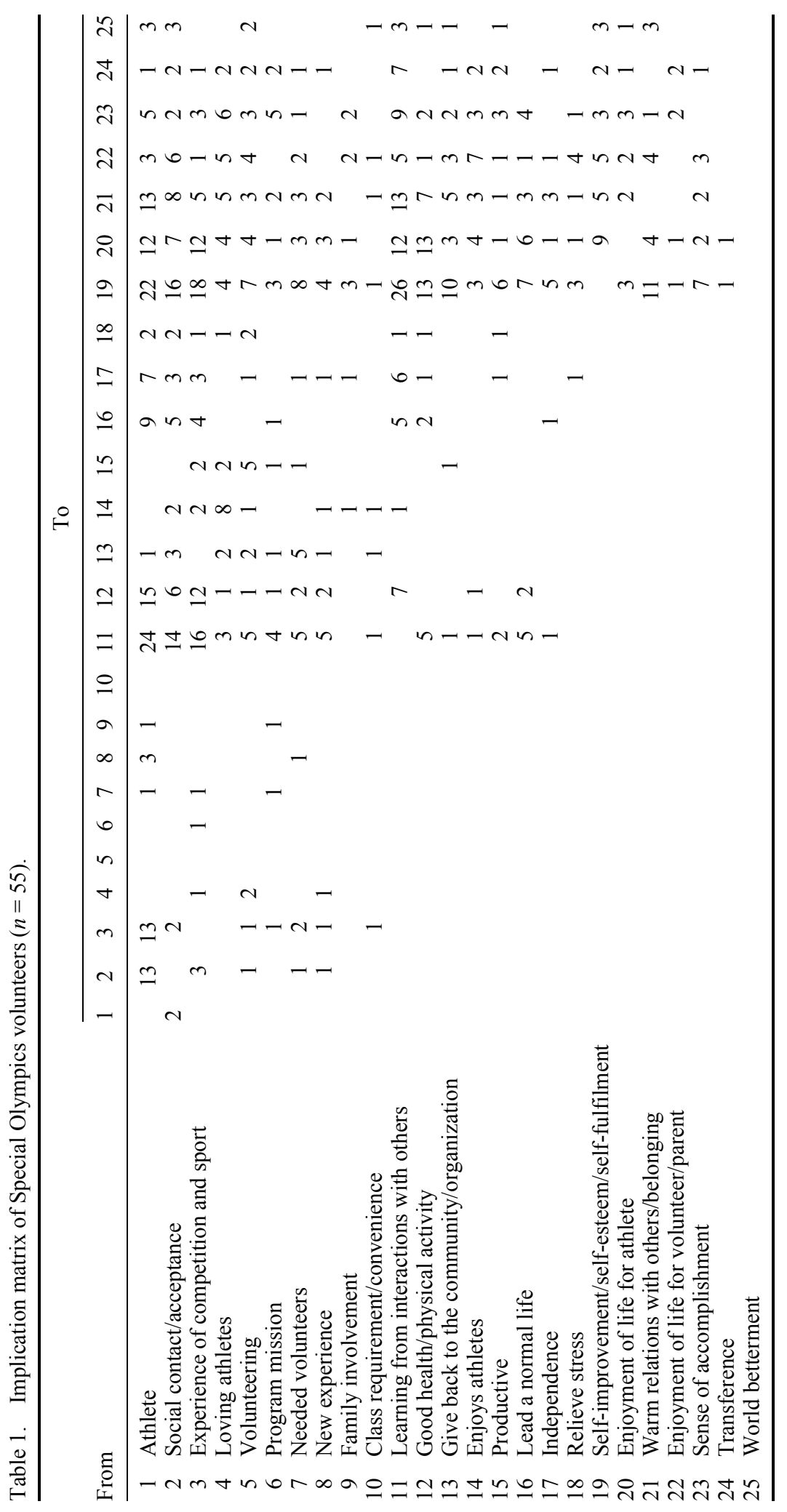


so that the overall themes could be seen on each HVM. In some cases, the cut-off points eliminated some of the attributes or consequences that did not have a high frequency.

The cut-off point chosen for the overall data HVM was 2. This cut-off point corresponded with $90.1 \%$ of the data being shown and 770 associations at or above this level. Cut-off points of 1 , representing $100 \%$ of the data, or 2 , representing $90.1 \%$ of the data, were used for all HVMs.

The HVMs for duration (0-12 months), hours per year (up to 60) and hours per year (60-200+) are shown with a cut-off level of 1, representing $100 \%$ of the corresponding data. The All Respondents HVM and duration (1 year or more) HVMs used the second cut-off values which were both approximately $90.1 \%$ of the data.

Five HVMs were created to make comparisons and answer research questions. These maps included the independent variables: hours donated per year, the length of time as a volunteer, and overall results. Four different answers to the duration question were available during the interview, but they were combined into two categories for the corresponding HVMs as was the case for the length of time volunteering. From the HVMs, conclusions were drawn and recommendations were made based on the findings.

\section{Results}

\section{Volunteer demographics}

A total of 55 individuals were interviewed as a convenience sample out of a total population of approximately 200 SLO County Special Olympics volunteers. Of the individuals interviewed, 15 were male and 40 were female. The respondents ranged in age from late teens to over 70 years. Most respondents were in their late 30 s. Over $47 \%$ had attended some college and over $36 \%$ of individuals were college graduates. Only 5\% did not graduate high school.

Length of time respondents had volunteered for the Special Olympics ranged from 1 month to over 20 years. Almost $40 \%(n=21)$ of those interviewed had volunteered for 10 or more years. Another large percentage of volunteers $(27.3 \%, n=15)$ had only volunteered for 1-5 months. Those who had volunteered for less than 1 year comprised $32.8 \%$ $(n=18)$ of the total volunteers and the rest had volunteered more than 1 year made up $(67.2 \%, n=37)$.

Individuals most commonly volunteered 200 plus hours per year, $(40 \%, n=22)$, or up to 20 hours per year $(36.4 \%, n=20)$. Participants who volunteered more between 60 and 100 hours comprised $14.5 \%(n=8)$ of study volunteers. Only $9.1 \%(n=5)$ of those interviewed volunteered from 20 to 59 hours per year $(n=5)$.

Study participants were asked the main volunteer position that they held. The most common volunteer position was helper at sports training, representing $27.3 \%$ of the sample. Head coach was the second largest position representing $23.6 \%$. Other frequent responses included 1-day sporting event volunteer (18.2\%), assistant coach, (14.5\%) and driver/chaperone $(10.9 \%)$.

\section{Frequency of content codes}

The final data analyzed were assigned in 25 different categories: 10 attributes, 8 consequences and 7 values, shown in Table 2 . Having an athlete in the program $(21.1 \%$ of all attributes mentioned) and wanting social contact/acceptance (19.9\% of all attributes mentioned) for themselves and/or for the athlete were the most often mentioned attributes. By far the most common consequence was learning from interactions with others $(39.3 \%$ of 
Table 2. Content codes defined (alphabetical listing).

\begin{tabular}{|c|c|}
\hline Attributes & Definition \\
\hline Athlete & $\begin{array}{l}\text { The interviewee is related to someone who is a } \\
\text { Special Olympics athlete }\end{array}$ \\
\hline Class requirement/convenience & $\begin{array}{l}\text { The volunteer experience was required for class or } \\
\text { it fits into the interviewee's schedule }\end{array}$ \\
\hline Experience of competition and sport & $\begin{array}{l}\text { Want athletes to have feeling of sport and } \\
\text { competition and/or volunteers like competition } \\
\text { and sports }\end{array}$ \\
\hline Family involvement & Volunteer to be a part of the relative (athletes) life \\
\hline Loving athletes & $\begin{array}{l}\text { The Special Olympic athletes have special } \\
\text { characteristics that making them loving }\end{array}$ \\
\hline Needed volunteers & The program needed volunteers \\
\hline New experience & $\begin{array}{l}\text { The interviewee wanted a new experience for } \\
\text { themselves, or for their relative who participates } \\
\text { in the Special Olympics }\end{array}$ \\
\hline Program mission & $\begin{array}{l}\text { Volunteer believes in the program mission and or } \\
\text { wants to help program grow }\end{array}$ \\
\hline Social contact/acceptance & $\begin{array}{l}\text { Volunteers for own social contact or so that their } \\
\text { child can have social contact or experience the } \\
\text { feeling of acceptance }\end{array}$ \\
\hline Volunteering & Overall idea/concept of a volunteer/volunteering \\
\hline Consequences & Definition \\
\hline Enjoys athletes & Volunteers enjoy athletes and their attitudes \\
\hline Give back to community and organization & $\begin{array}{l}\text { Through volunteering one can give back to the } \\
\text { community and the Special Olympics }\end{array}$ \\
\hline Good health/physical activity & $\begin{array}{l}\text { Special Olympics promotes this and athletes } \\
\text { receive this by participating }\end{array}$ \\
\hline Independence & $\begin{array}{l}\text { The Special Olympics helps create independence } \\
\text { for the athlete }\end{array}$ \\
\hline Lead a normal life & Program helps athletes to lead a normal life \\
\hline Learning from interactions with others & Any type of learning by interaction with others \\
\hline Productive use of time & $\begin{array}{l}\text { Volunteering for the Special Olympics is a good } \\
\text { use of the volunteers time }\end{array}$ \\
\hline Relieve stress & Relief of stress for the volunteer and or athlete \\
\hline Values & Definition \\
\hline Enjoyment of life for athlete & Enjoyment of life for athlete \\
\hline Enjoyment of life for volunteer/parent & Enjoyment of life for the volunteer and or parent \\
\hline $\begin{array}{l}\text { Self-improvement/self-esteem/ } \\
\text { self-fulfilment }\end{array}$ & $\begin{array}{l}\text { Improve self-esteem, improve one's self and fulfil } \\
\text { own goals and expectations }\end{array}$ \\
\hline Sense of accomplishment & Volunteers feel this and or athletes feel this \\
\hline Transference to life & $\begin{array}{l}\text { Experience of volunteering, or participating in } \\
\text { Special Olympics affects other aspects of } \\
\text { volunteers (athletes) life/carries over }\end{array}$ \\
\hline Warm relations with others/belonging & Friendships created and feeling of belonging to a group \\
\hline World betterment & Make the world a better place for others \\
\hline
\end{tabular}

all consequences mentioned). The most mentioned value and overall concept was selfimprovement/self-esteem/self-fulfilment (33.7\% of values mentioned) (Table 3 ).

The primary attribute throughout the data was that the volunteer was associated with an athlete participating in the program (usually a son or daughter). The second most mentioned attribute was that the SLO Country Special Olympics provides social contact/ acceptance for volunteers and athletes. The third most mentioned attribute was for the 
athlete to experience competition and sport. This was important for the volunteers who enjoy sports themselves and found it as a way to connect with others. It was also important for the parents who wanted their child to play on a team. Also important were the athletes themselves, as their attitudes attract volunteers. The act of volunteering and the fact that the organization needed volunteers were mentioned frequently.

A total of 114 ladders were generated from the 55 individuals interviewed. The average number of ladders generated from each individual was 2.07. The mode of ladders collected was 2.0. The lowest number of ladders completed was 1 and the highest was 5 (Table 3 ).

\section{Means-end associations}

Five HVMs were created to answer the research questions. Each HVM is associated with a certain demographic, for example, answers of all individuals who volunteered 60 hours or more. On the HVMs, attributes were shown at the bottom of the page, with the name of the attribute written in all lowercase text and in the color of white. Above the attributes were consequences which were represented by grey circles titled with upper and lowercase text. Above consequences were values which were represented by black circles titled with all uppercase text.

Table 3. Frequency of content codes in respondents' ladders.

\begin{tabular}{lrr}
\hline Concepts & $n$ & Pct. \\
\hline Attributes & & \\
Athlete & 33 & 21.1 \\
Social contact/acceptance & 31 & 19.9 \\
Experience of competition and sport & 26 & 16.7 \\
Loving athletes & 15 & 9.6 \\
Volunteering & 15 & 9.6 \\
Needed volunteers & 10 & 6.4 \\
Program mission & 10 & 6.4 \\
New experience & 7 & 4.5 \\
Family involvement & 5 & 3.2 \\
Class requirement/convenience & 4 & 2.6 \\
Total & 156 & 100.0 \\
Consequences & & \\
Learning from interactions with others & 57 & 39.3 \\
Good health/physical activity & 21 & 14.5 \\
Give back to community and organization & 15 & 10.3 \\
Enjoys athletes & 14 & 9.7 \\
Lead a normal life & 11 & 7.6 \\
Productive use of time & 11 & 7.6 \\
Independence & 10 & 6.9 \\
Relieve stress & 6 & 4.1 \\
Total & 145 & 100.0 \\
Values & & \\
Self-improvement/self-esteem/self-fulfilment & 62 & 33.7 \\
Enjoyment of life for athlete & 30 & 16.3 \\
Warm relations with others/belonging & 29 & 15.7 \\
Enjoyment of life for volunteer/parent & 22 & 12.0 \\
Sense of accomplishment & 21 & 11.4 \\
Transference to life & 11 & 6.0 \\
World betterment & 9 & 4.9 \\
Total & & 100.0 \\
\hline & & \\
& &
\end{tabular}




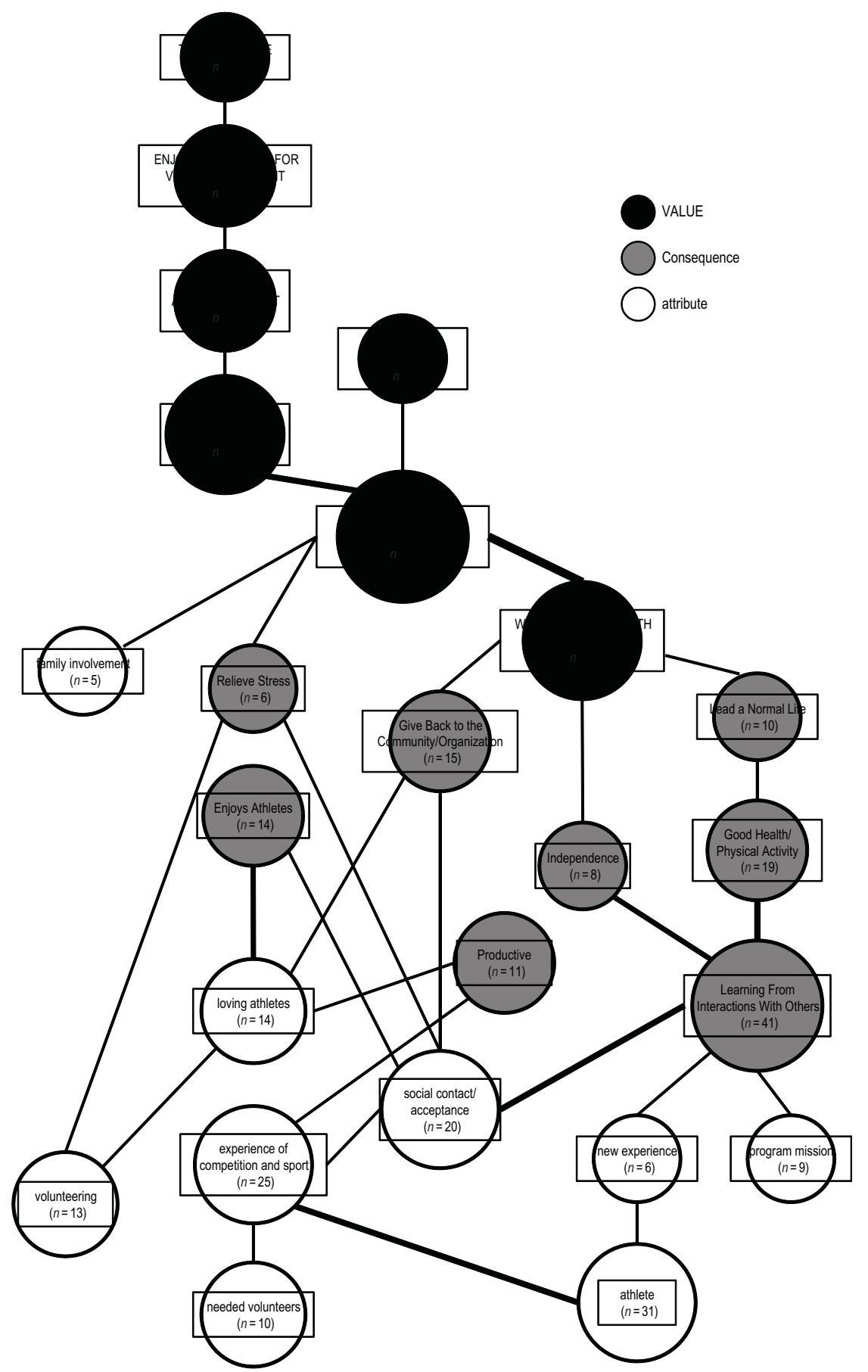

Figure 1. Hierarchical value map for Special Olympics volunteers - All $(n=55)$.

Based on the HVM for all respondents (see Figure 1), the most represented attributes were "athlete" and "experience of competition and sport," which also showed a fairly strong link. The associations between the attributes "program mission," "new experience" 
and "social contact/acceptance" were all very strongly linked to the consequence of "learning from interactions with others." There was also a very strong link between "learning from interactions with others" and "good health/physical activity." Between consequences and values, there was a very strong link between "giving back to the community/organization" and "warm relations with others/belonging." Within the values there was a fairly strong link between "warm relations with others/belonging" and "selfimprovement/self-esteem/self-fulfilment."

Only 9 of the 10 attributes were listed. This was because the attribute "class requirement" was not mentioned frequently enough to show up after the second cut-off point. The attributes that were mentioned the least number of times were "family involvement" $(n=5)$ and "new experience" $(n=6)$. The least important consequence was to "relieve stress" $(n=6)$. The only value that was not mentioned frequently was "world betterment" $(n=5)$ (see Figure 1.1).

The following two HVMs distinguish between participants based on the length of time they had volunteered. The first HVM portrays individuals who had volunteered less than a year (see Figure 2) and the second HVM describes those who had volunteered 1 or more years (see Figure 3).

The similarities between those who volunteer less than a year and those for more than a year were based primarily on the main consequences and values they mentioned. Both reported the consequence "learning from interactions with others" most often and the value "self-improvement/self-esteem/self-fulfilment" most often. There were no strong relationships between any concepts on the HVM of those who had volunteered less than a year. The attribute "family involvement" was not mentioned nor was the consequence of "independence."

The HVM of those who had volunteered 1 or more years revealed several very strong links. This HVM did not include the attribute of "class requirement/convenience." The strongest links occurred between the attribute "loving athletes" and the consequence "enjoys athletes." There was also a very strong link between the attribute "social contact/ acceptance" and the consequence of "learning from interactions with others." There was an especially strong link from consequence to value with "learning from interactions with others" and "transference." Finally, there was an extremely strong relationship between the two values: "giving back to the community/organization" and "warm relations with others/belonging."

The next two HVMs were based on hours per year volunteered. The data for hours volunteered per year were broken down into two categories for the corresponding HVMs: those volunteers who put in 60 or less hours per year and those who put in 61-200 hours or more.

The volunteers that donated 60 hours or less per year had no strong links between or within the attributes, consequences or values (see Figure 4). The most mentioned attribute, consequence and value were "experience of competition and sport," "learning from interactions with others" and "self-improvement/self-esteem/self-fulfilment," respectfully. They had one relatively strong link between "good health/physical activity" and "learning from interactions with others." The other relatively strong link was in values relating "sense of accomplishment" and "self-improvement/self-esteem/self-fulfilment."

Those individuals who volunteered between 61 and 200 or more hours a year had many strong relationships and links (see Figure 5). Again, the attribute of "class requirement/convenience" did not appear. The strongest attribute was "athletes," which also differed from the first group. Similar to the first group, the strongest consequence and value for individuals volunteering 61-200 plus hours were "learning from interactions with 


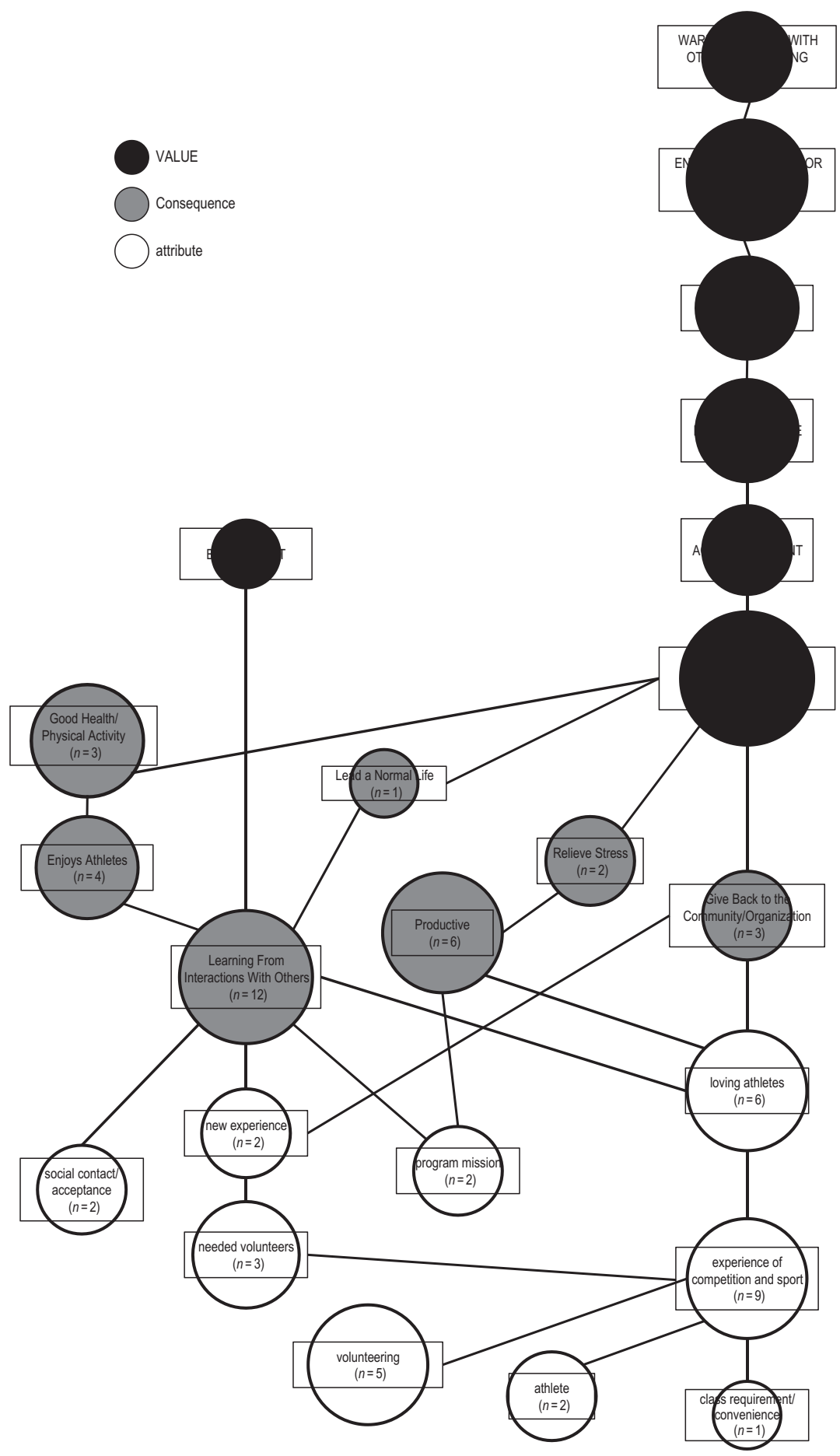

Figure 2. Hierarchical value map for Special Olympics volunteers - Duration 1 year or less $(n=26)$. 


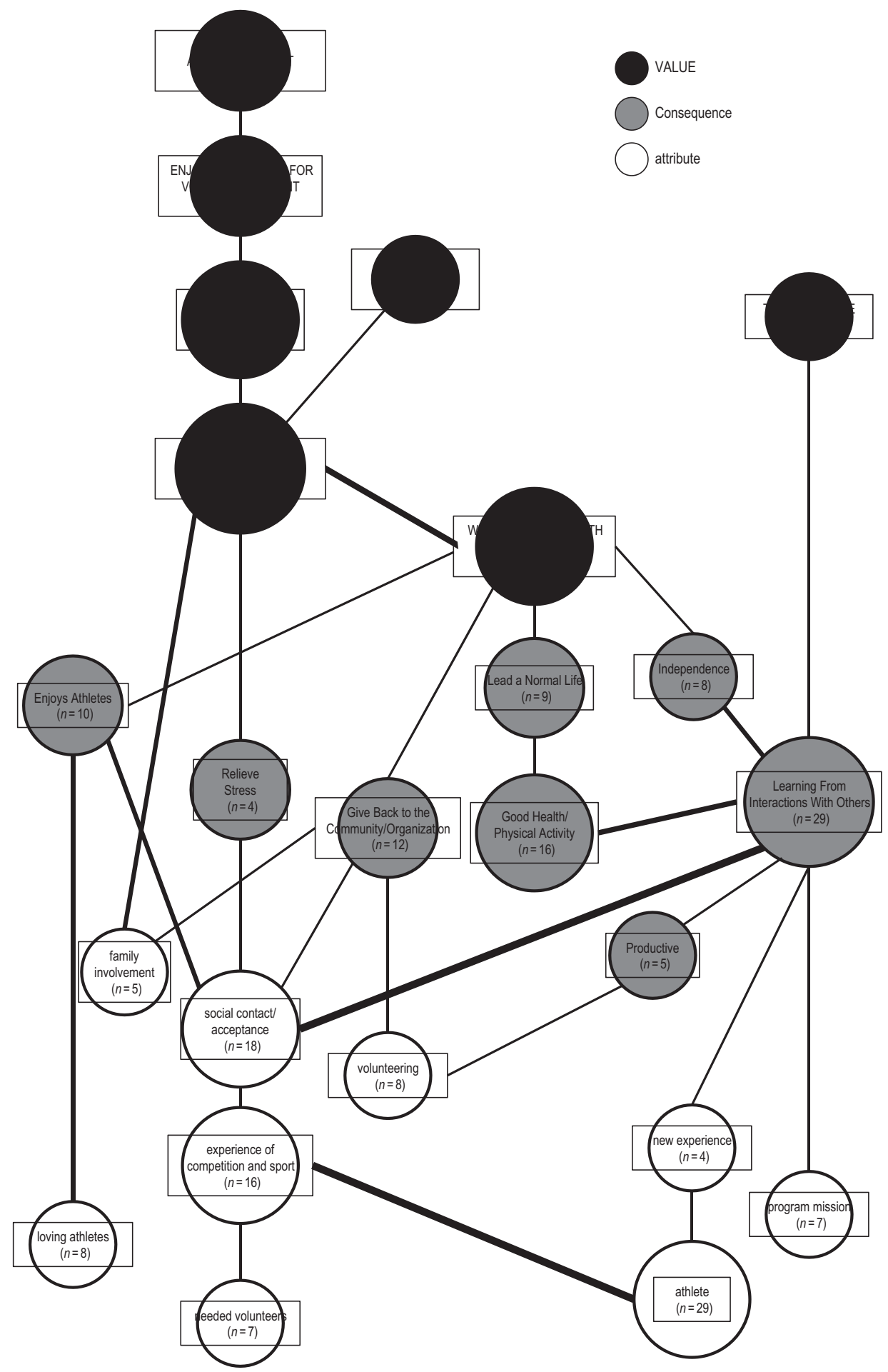

Figure 3. Hierarchical value map for Special Olympics volunteers - Duration more than 1 year $(n=29)$. 


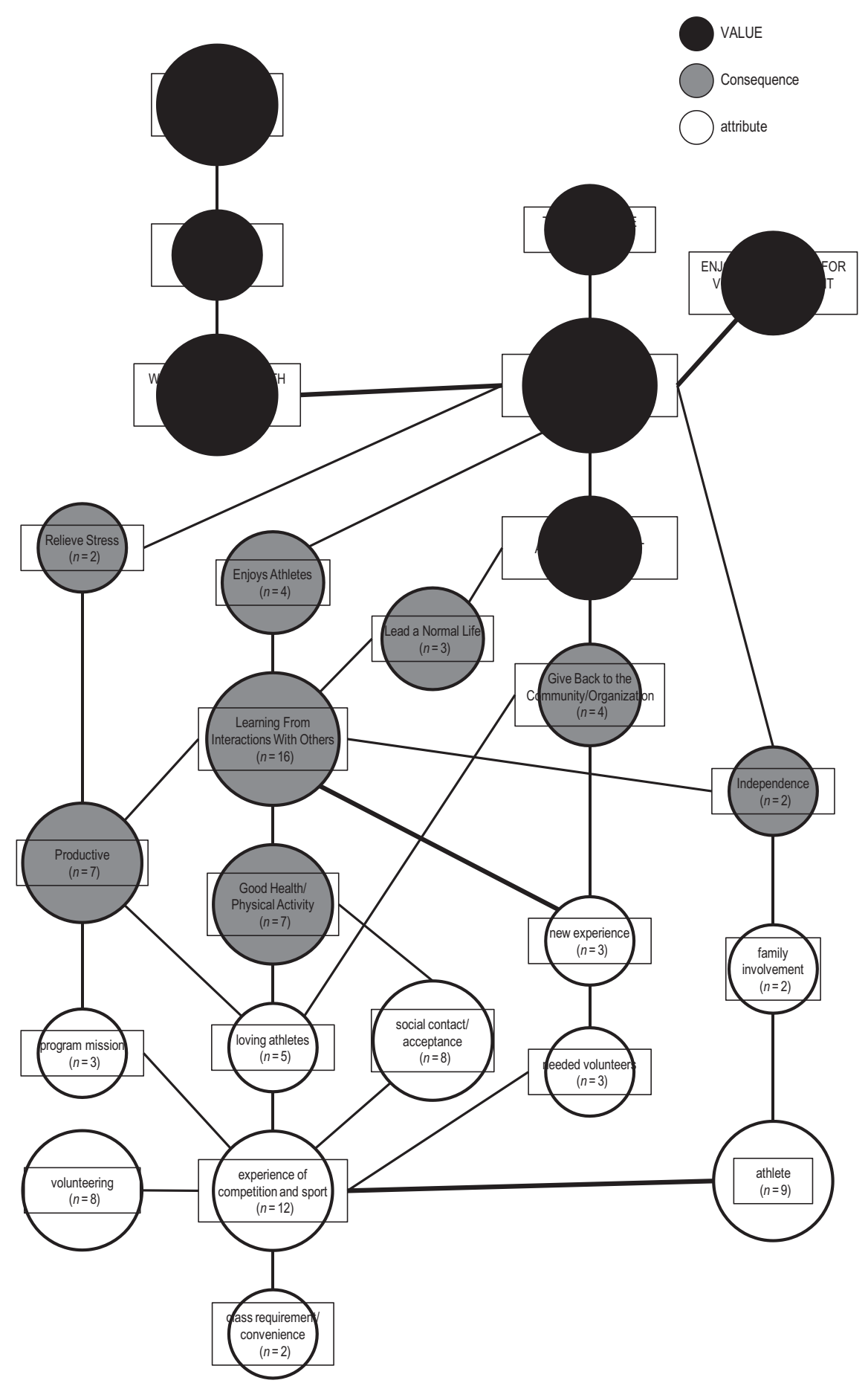

Figure 4. Hierarchical value map for Special Olympics volunteers - Hours donated 10-60 $(n=25)$. 


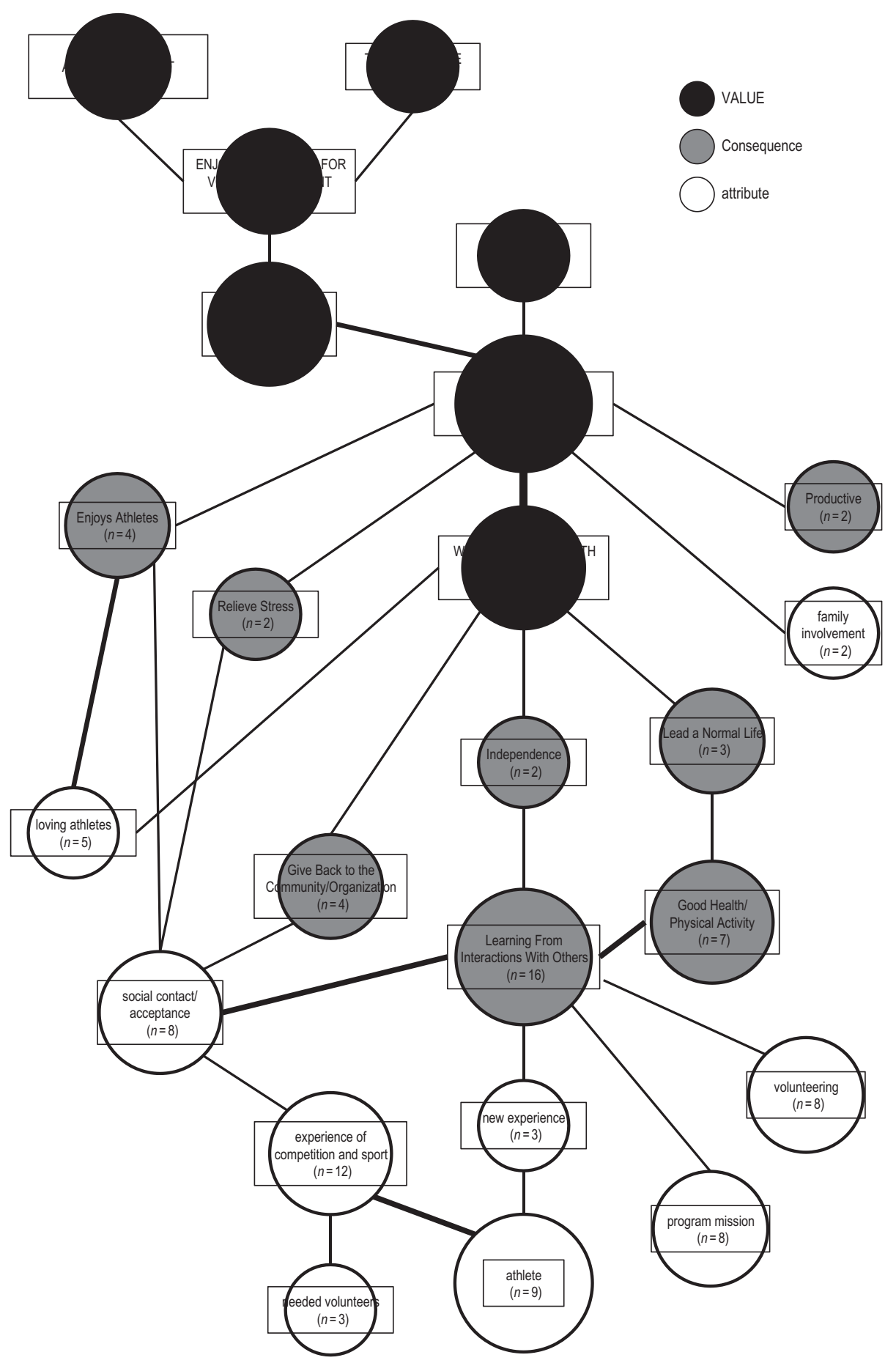

Figure 5. Hierarchical value map for Special Olympics volunteers - Hours donated 61-200 $(n=30)$. 
others" and "self-improvement/self-esteem/self-fulfilment." The strong links between attributes and consequences occurred between "loving athletes" and "enjoy athletes" and between "social contact/acceptance" and "learning from interactions with others." The strongest links between a consequence and a value were "give back to the community/ organization" and "warm relations with others/belonging." There was also a strong relationship within the values of "warm relations with others/belonging" and "self-improvement/ self-esteem/self-fulfilment."

\section{Results and discussion}

This study examined the reasons individuals volunteer for a Special Olympics organization, including the values associated with volunteering. To this end, a means-end theory approach was used to determine the attributes, consequences and values associated with volunteering for the Special Olympics.

The values identified in this study were provided by volunteers but involved improvement in the life of themselves and the lives of the athletes. As many volunteers were friends or family members of athletes, the values that the study participants associate with volunteering specifically benefit the athlete. Some volunteers witness the positive effects of sports on the athlete and being able to help provide this opportunity for the athlete also provides benefits for the volunteer. Even though the volunteer is the subject of the study, the attributes, consequences and values that parents believe the athletes receive are included in their own attributes, consequences and values.

Those who had volunteered for over a year usually had a child in the program. They had their child involved so that he or she could experience competition and sports, to have social contact and feel accepted. The volunteers felt that these characteristics of the program led the athlete to learn from their interactions with others and create their own independence. Parent volunteers believed competition and sporting aspect provided the athletes with good health and physical activity. This leads to the athlete and often the parent feeling a sense of self-improvement, increased self-esteem and self-fulfilment. This in turn led to the athlete's enjoyment of life, warm relations with others and a sense of belonging.

Of those who had volunteered 1 year or less, most did not have a child in the program. They chose this volunteer experience because of the sport aspect and the athletes. The most frequently mentioned consequence was learning from interactions with others, which the two most often mention attributes (the experience of competition and sport and having an athlete in the program) were linked. Learning from interactions with others was linked to the value of self-improvement/self-esteem/self-fulfilment, which led to all other values, except for world betterment. The other most important value was enjoyment of life for volunteer/parent.

The amount of time volunteered per year was associated with the individuals' reasons for volunteering and their values. The results for those who volunteered less than 60 hours were very similar to the results for those who had been volunteering for a year or less in regard to this sample of Special Olympics volunteers. There were not any strong relationships between any attributes, consequences and values. The "experience of competition and sport" was the most important reason for volunteering and having an athlete in the program was also one of the more common reasons. These both eventually lead to the important consequence of "learning from interactions with others." Similar to other subgroups in the sample, the most mentioned value for those volunteering less than 60 hours per year was "self-improvement/self-esteem/self-fulfilment" which was strongly linked to "enjoyment of life for the athlete." 
Most individuals who volunteered over 61 hours had a son or daughter in the program. They wanted their son or daughter to have the experience of sports and social contact/ acceptance. From these attributes, the parents believed the athlete would learn from interactions with others, have physical activity and good health. This would lead to independence and a more social, healthy life. These consequences led to warm relations with others and a sense of belonging which led to self-improvement, self-esteem and self-fulfilment which lead to the enjoyment of life for the athlete.

The final area examined was the values that individuals associate with volunteering. The most frequently mentioned values include self-improvement, self-esteem and self-fulfilment for the volunteers. Other frequently mentioned values were warm relations with others and a sense of belonging, enjoyment of life for the volunteer, enjoyment of life for the athlete and a sense of accomplishment. Values mentioned less frequently were transference to life and world betterment.

The value of "world betterment" is similar to the values function mentioned in the List of Values (Kahle, 1983; Veroff et al., 1981). World betterment is the value of making the world a better place to live and similarly the values function pertains to altruistic goals. The value of "world betterment" has also been identified in recreation-based means-end research (Goldenberg et al., 2006)

"Transference," though not mentioned in the List of Values, has been found in previous means-end research (Goldenberg, 2002). This value illustrates the benefits of volunteering transferring to general, activities, life, nature and work/school. Transference is the experience of volunteering or participating in Special Olympics and taking what is learned or perceived and then applying it to other aspects of volunteers (athletes) life. An example of transference is a parent volunteer has their child participate in Special Olympics sports, this leads to new experiences for the athlete, which in turn leads to learning from interactions with others which leads to the athlete being able to function more easily in other social situations.

\section{Conclusions and recommendations}

Many volunteer studies use the volunteer functions inventory created by Clary et al. (1992) when looking at volunteer motivation (Allison et al., 2002; Clary et al., 1992, 1996, 1998; Fletcher \& Major, 2004; Greenslade \& White, 2005). Many of these functions were found in the reasons why individuals volunteer for Special Olympics. The values function from the volunteer functions inventory (Clary et al., 1992) was illustrated in the attributes of "needed volunteers," "volunteering" and "program mission," in the consequence "give back to the community/organization," the value of "world betterment" and "enjoyment of life for athlete." The understanding function is illustrated in the "new experiences" attribute. The enhancement function is shown as the attribute "social contact/acceptance," the consequence, "learning from interactions with others," the values of "self-improvement/self-esteem/self-fulfilment" and "sense of accomplishment." The career function was not a main theme but was evident in the attribute "class requirement/convenience," consequence of "productive use of time" and the value "transference to life." The social function and protective function were not mentioned by Special Olympics volunteers.

This study on volunteering also aligns with previous general values research. Of the values stated in the List of Values (Kahle, 1983; Veroff et al., 1981), a sense of belonging, warm relations with others, self-fulfilment, fun and enjoyment of life and a sense of accomplishment were all mentioned in this study on Special Olympic volunteers. These 
particular values resonate with the volunteers because they care about the individuals who participate in Special Olympics. The volunteers want to feel as part of an organization and create relationships with others, as well as gaining personal fulfilment and a sense of accomplishment, while enjoying life. The values of self-improvement and self-esteem that were mentioned in this study were similar to the values of self-respect and being well respected (Kahle, 1983; Veroff et al., 1981). The value of security was not mentioned nor was the value of excitement in this study. Rather, the two additional values, world betterment and transference to life, were mentioned by Special Olympic volunteers.

This study showed that volunteers for the Special Olympics associate many important values with volunteering, and this specific information can have many practical implications. This information can be used while creating marketing plans for recruiting volunteers and athletes. For example, the Special Olympics could do a marketing campaign directed toward non-parent volunteers and new potential volunteers focusing on the outcomes a volunteer receives while being a part of the Special Olympics including such as having good relationships with others and a sense of belonging to a group.

As this study showed that most volunteers have an athlete in the program, another marketing campaign could be directed at recruiting new parent volunteers by focusing on the outcomes that the parents and athletes receive. For example, when the parent volunteers interact with other parent volunteers they know that there is an unsaid understanding and acceptance which they do not get from any other social groups, as stated by numerous parent volunteers during the interview process. While the parents will have a new supportive community, seeing their child happy will also make the parent volunteer happy and improves the life of the parent volunteer.

Volunteers in this study appear to be of two types: those who have been involved in the program for less than a year and donate less than 60 hours a year; and those who have been involved with the program for over 5 years and donate hundreds of hours per year. The Special Olympics must retain the current seasoned volunteers by continuing to provide them with what they think is important, a great social and sport activity for their son or daughter and a place for the parent to socialize and feel accepted. During interviews, seasoned volunteers stated that they have seen the difference the program makes in the lives of the athletes, which is why they have continued to volunteer. The Special Olympics should remind these volunteers that this athletic opportunity would not be possible without their support. This type of recognition reinforces the importance of their volunteering and identifies with the reason they volunteer in the first place, which is to make the opportunity available for their child.

The Special Olympics should also focus on the volunteers who have been part of the organization for less than a year. These are the individuals who might not know the importance of the benefits that they will receive and/or the benefits that the athletes receive. There should be information given to all new or potential volunteers which illustrates the benefits, specifically the ones that were the main themes in this research.

This research shows that means-end theory can be applied to the volunteer field and can add to the body of knowledge by examining the attributes, consequences and values of a leisure experience. This approach links the attributes, consequences and values together to gain an understanding of the values reached for individuals. As the parent volunteers value the improvement in the quality of life of their child athlete experiences due to the Special Olympics the parent becomes a highly vested volunteer. With this dedication to volunteering much data and higher level values can be collected and evaluated. These results help contribute to the research of volunteer demographics, reasons for volunteering and values associated with volunteering. 
This research also indicates that individuals will volunteer for decades at a time for the Special Olympics, as long as they are receiving the outcomes they deem important. In the case of this not-for-profit organization, volunteers (mainly parents) will volunteer as long as their children are receiving benefits from the Special Olympics such as self-improvement/ self-esteem/self-fulfilment and the program brings happiness into the lives of the volunteer and the athlete. Although this study lent support to the findings of past volunteer, means-end and values research, many more studies must be undertaken to gain a better understanding of volunteers and their reasons for volunteering.

The limitations of this study are that only volunteers from one local chapter of a national organization. The results may not be able to be generalized to other Special Olympic locations. The sample was a convenience sample, those located at various sporting events during a 4-month period in SLO County, CA, USA.

The following are suggestions for additional research based on this study. A larger study with more participants could be undertaken to further validate the themes from this research. A comparison of athletes' parents who volunteer to non-volunteer parents would also be useful. An understanding of the differences between the two would enables the Special Olympics to recruit parents who currently do not donate their time by highlighting the most important benefits that current parent volunteers receive. Understanding these differences could also help marketing and managing non-parent volunteers by concentrating on the critical benefits received.

Additional studies could be conducted in other Special Olympics locations and compare results to see if the demographics and reasons for volunteering are similar across all Special Olympics regional locations. A similar study could be done with a not-for-profit organization from another sector such as health or social service. These results could then be compared to this study to determine if the results are similar and thus implications may be applied to other not-for-profits.

Future research may divide up the data into athlete benefits and benefits specific to volunteers. Many volunteers listed their reasons for volunteering all relating to the athlete, and the many different ways the Special Olympics benefits the athlete, yet these same volunteers also list the direct and indirect benefits the Special Olympics had on them personally. It may be valuable for the future researchers to have separate attributes, consequences and values for volunteers and or child athletes.

\section{References}

Allison, L.D., Okun, M.A., \& Dutridge, K.S. (2002). Assessing volunteer motives: A comparison of an open-ended probe and Likert rating scales. Journal of Community \& Applied Social Psychology, $12,234-255$.

Bagozzi, R.P., \& Dabholkar, P.A. (1994). Consumer recycling goals and their effect on decisions to recycle: A means-end chain analysis. Psychology and Marketing, 11, 313-340.

Baker, S., Thompson, K.E., \& Engelken, J. (2004). Mapping the values driving organic food choice: Germany vs the UK. European Journal of Marketing, 38, 995-1012.

Bearden, R., Netemeyer, R., \& Mobley, M. (1993). Handbook of marketing scales: Multi-item measures for marketing and consumer behavior research. Newbury Park, CA: Sage.

Clary, E.G., Snyder, M., \& Ridge, R.D. (1992). Volunteers motivations: A functional strategy for the recruitment, placement, and retention of volunteers. Nonprofit Management and Leadership, 2, 330-350.

Clary, E.G., Snyder, M., Ridge, R.D., Copeland, J., Stukas, A.A., Haugen, J., \& Miene, P. (1998). Understanding and assessing the motivation of volunteers: A functional approach. Journal of Personality and Social Psychology, 74, 1516-1530.

Clary, E.G., Snyder, M., \& Stukas, A.A. (1996). Volunteers motivations: Findings from a national survey. Nonprofit and Voluntary Sector Quarterly, 25, 485-505. 
Costa, A.I.A., Dekker, M., \& Jongen, W.M.F. (2004). An overview of means-end theory: Potential application in consumer-oriented food product design. Trends in Food Science \& Technology, $15,403-415$.

Ellis, S.J. (2005). Tracking volunteer trends: As the world changes, so do trends in volunteerism. Here's how to maintain a strong volunteer base. Association Management, 57(1), 72-75.

Feather, N.T. (1975). Values in education and society. New York: Free Press.

Finkelstein, M.A., \& Penner, L.A. (2004). Predicting organizational citizenship behavior: Integrating the functional and role identity approaches. Social Behavior and Personality, 3, 383-398.

Fletcher, T.D., \& Major, D.A. (2004). Medical students' motivations to volunteer: An examination of the nature of sexual differences. Sex Roles, 51(1/2), 109-114.

Frauman, E., \& Cunningham, P.H. (2001). Using a means-end approach to understanding the factors that influence greenway use. Journal of Park and Recreation Administration, 193, 93-113.

Gengler, C.E., Mulvey, M.S., \& Oglethorpe, J.E. (1999). A means-end analysis of mothers' infant feeding choices. Journal of Public Policy \& Marketing, 182, 172-188.

Gengler, C.E., \& Reynolds, T.J. (1995). LadderMap [Computer software]. Camden, NJ: Means-End Software.

Goldenberg, M.A. (1997). Understanding the benefits of ropes course experiences using means-end analysis (Unpublished master's thesis). Purdue University, West Lafayette, IN.

Goldenberg, M.A. (2002). Understanding the outcomes of outdoor adventure experiences using meansend analysis (Unpublished doctoral dissertation). University of Minnesota, Twin Cities, MN.

Goldenberg, M.A., Klenosky, D.B., O'Leary, J.T., \& Templin, T.J. (2000). A means-end investigation of ropes course experiences. Journal of Leisure Research, 32, 208-224.

Goldenberg, M.A., McAvoy, L., \& Klenosky, D. (2005). Outcomes from the components of an outward bound experience. Journal of Experiential Education, 28, 123-146.

Goldenberg, M.A., Pronsolino, D., \& Klenosky, D.B. (2006). An employee perspective of service in an outdoor education organization: A means-end study. Research in Outdoor Education, 8 , 94-104.

Graeff, T.R. (1997). Comprehending product attributes and benefits: The role of product knowledge and means-end chain inferences. Psychology \& Marketing, 14, 163-183.

Greenslade, J.H., \& White, K.M. (2005). The prediction of above average participation in volunteerism: A test of the theory of planned behavior and the volunteers functions inventory in older Australian adults. The Journal of Social Psychology, 145, 155-172.

Gutman, J. (1982). A means-end chain model based on consumer categorization processes. Journal of Marketing, 46, 60-72.

Gutman, J. (1984). Analyzing consumer orientations toward beverages through means-end chain analysis. Psychology \& Marketing, 1, 23.

Gutman, J. (1997). Means-end chains as goal hierarchies. Psychology \& Marketing, 14, 545-560.

Gutman, J., \& Miaoulis, G. (2003). Communicating a quality position in service delivery: An application in higher education. Managing Service Quality, 13, 105-112.

Houle, B.J. (2001). Functional approach to volunteerism: An investigation of motives, choice, and task planning (Unpublished master's thesis). Northern Illinois University, DeKalb, IL.

Hoye, R. (2004). Leader member exchanges and board performance of voluntary sport organizations. Nonprofit Management \& Leadership, 15(1), 55-70.

Hustinx, L., \& Lammertyn, F. (2004). The cultural bases of volunteering: Understanding and predicting attitudinal differences between Flemish Red Cross volunteers. Nonprofit and Voluntary Sector Quarterly, 33, 548-584.

Iso-Ahola, S. (1999). Motivational foundations of leisure. In E.L. Jackson \& T.L. Burton (Eds.), Leisure studies prospects of the twenty-first century (pp. 35-51). State College, PA: Venture.

Jansen-Verbeke, M., \& van Rekom, J. (1996). Scanning museum visitors. Annals of Tourism Research, 23, 364-375.

Jimenez, M.L.V., \& Fuertes, F.C. (2005). Positive emotions in volunteerism. The Spanish Journal of Psychology, 8(1), 30-35.

Kahle, L. (Ed.). (1983). Social values and social change: Adaptation to life in America. New York: Praeger.

Klenosky, D.B., Gengler, C.E., \& Mulvey, M.S. (1993). Understanding the factors influencing ski destination choice: A means-end analytic approach. Journal of Leisure Research, 25, 362-380.

Manfredo, M.J., Driver, B.L., \& Tarrant, M.A. (1996). Measuring leisure motivation: A metaanalysis of the recreation experience preference scales. Journal of Leisure Research, 28, 188-213. 
Manyiwa, S., \& Crawford, I. (2002). Determining linkages between consumer choices in a social context and the consumer's values: A means-end approach. Journal of Consumer Behavior, 2(1), 54-70.

Maslow, A.H. (1954). Motivation and personality. New York: Harper.

McAvoy, L., Holman, T., Goldenberg, M., \& Klenosky, D. (2006). Wilderness and persons with disabilities: Transferring the benefits to everyday life. International Journal of Wilderness, 12, 23-35.

Penner, L.A. (2004). Volunteerism and special problems: Making things better or worse? Journal of Social Issues, 60, 645-666.

Pieters, R., Baumgartner, H., \& Allen, D. (1995). A means-end chain approach to consumer goal structures. International Journal of Research in Marketing, 12, 227-244.

Rehberg, W. (2005). Altruistic individuals: Motivations for international volunteering among young adults in Switzerland. Voluntas: International Journal of Voluntary and Nonprofit Organizations, 16, 109-122.

Rokeach, M.J. (1973). The nature of human values. New York: Free Press.

Special Olympics. (n.d.). Volunteer your time. Retrieved from http://www.sosc.org/ Volunteer Main.htm

Twynam, D.G., Farrell, J.M., \& Johnston, M.E. (2002/2003). Leisure and volunteer motivation at a special sporting event. Leisure/Loisir, 27, 363-377.

Veroff, J., Douvan, E., \& Kulka, R. (1981). The inner America. New York: Basic Books.

Walker, B. (1988). Integrating self, motivation and situations: A cognitive structure model of self/ product relationships (Unpublished doctoral dissertation). Pennsylvania State University, University Park, PA

Winter, M. (1998). Themes for volunteering emerge from forum. Human Ecology Forum, $26,7$. 